\title{
Identification of Erwinia amylovora by Growth Morphology on Agar Containing Copper Sulfate and by Capsule Staining with Lectin
}

\author{
Stefan Bereswill, Susanne Jock, Peter Bellemann, and Klaus Geider, Max-Planck-Institut für Zellbiologie, Ro- \\ senhof, D-68526 Ladenburg, Germany
}

\begin{abstract}
Bereswill, S., Jock, S., Bellemann, P., and Geider, K. 1998. Identification of Erwinia amylovora by growth morphology on agar containing copper sulfate and by capsule staining with lectin. Plant Dis. 82:158-164.

Erwinia amylovora strains formed yellow colonies on minimal agar medium MM2 containing asparagine and copper sulfate (MM2Cu), in contrast to a white morphology on minimal agar without copper salt. Additionally, the colonies were mucoid to various extents. The yellow color was characteristic for the fire blight pathogen, including strains from raspberry and from other unusual host plants, and was used to establish a novel plating technique for identification of $E$. amylovora. The new identification method was especially superior to semi-selective media with sucrose when natural levan-deficient strains were assayed. No growth of E. amylovora was observed for the similar medium MM1 containing $2 \mathrm{mM} \mathrm{CuSO}_{4}$, due to its low content of asparagine. Identification by colony morphology on MM2 agar with copper was confirmed by staining the bacterial capsules with FITC-labeled lectin from Abrus precatorious, a compound which has a high affinity for galactose residues, the main sugar in the capsular exopolysaccharide amylovoran of E. amylovora. Other plant-associated bacteria usually did not produce the typical colony morphology of E. amylovora on MM2 agar with copper. Furthermore, those cells were not stained with the Abrus lectin. Capsule staining was also observed for weakly mucoid strains of E. amylovora, but not for strains with mutations affecting amylovoran synthesis. The secretion of fluorescent compounds by Pseudomonas syringae pathovars and even growth of any other bacterial colonies adjacent to E. amylovora could interfere with the formation of typical yellow colonies on $\mathrm{MM} 2 \mathrm{Cu}$, which could be white in case of dense plating. After screening for white colonies on LB agar, E. amylovora was identified in extracts from Cotoneaster leaves and in bark from apple trees with fire blight symptoms by its yellow growth pattern on $\mathrm{MM} 2 \mathrm{Cu}$ agar and by capsule staining. The proposed selective medium gives a clear signal, is easy to prepare, does not contain dyes or any compounds toxic to humans, and can also detect E. amylovora strains deficient in levan synthesis.
\end{abstract}

Additional keywords: amylovoran synthesis, copper resistance, plant-associated bacteria

Fire blight, a bacteriosis of pome fruit trees and other rosaceaous plants (30), can be disastrous in apple and pear orchards and is therefore of great economic importance. First noticed in the eighteenth century in North America, the disease has been spread in this century to many parts of the world. More than 30 countries have reported the occurrence of fire blight, although regions exist without reports of the disease. Strategies to control fire blight include monitoring the pathogen, pruning and eradication of plants with disease symptoms, and spraying of bactericidal compounds.

For identification of the causative agent, the Gram-negative bacterium Erwinia amylovora, various tools have been devel-

Corresponding author: Klaus Geider

E-mail: kgeider@zellbio.mpg.de

Accepted for publication 30 September 1997.

Publication no. D-1997-1203-02R

(C) 1998 The American Phytopathological Society oped: (i) semi-selective agar plates; (ii) serological assays such as enzyme-linked immunosorbent assay (ELISA) and immunofluorescence (IF); and (iii) DNA hybridization and polymerase chain reaction (PCR) techniques. Many semi-selective media were suggested to detect $E$. amylovora (30). Except MS-agar proposed by Miller and Schroth (23), most of them contain sucrose as carbon source. Sucrosebased media were suggested by Kado and Heskett (D3; 17), Lelliott (SNA; 19), Crosse and Goodman (CG-agar; 9), and were further modified by Brulez and Zeller (NSA; 7). Dyes in the media indicate a $\mathrm{pH}$ shift caused by the production of acids from metabolized sugars and give the smooth colonies an orange appearance (Fig. 1D). Like many plant-associated bacteria, most E. amylovora strains secrete the levan-forming enzyme levansucrase (12) Occasionally, levan-deficient strains have been isolated from plant tissue with fire blight symptoms (5). Those variants would not be detected on semi-selective agar with sucrose. The production of levan on NSA agar by other bacteria can be mis- leading for the detection of E. amylovora. On MS agar, colony morphology of $E$. amylovora can be ambiguous, especially when cells of E. herbicola are present in the same sample. An additional semiselective medium, CCT, was therefore suggested (16), which contains sucrose and sorbitol as carbon sources. E. amylovora grows in translucent colonies on this medium and can be differentiated from $E$. herbicola. Pseudomonas syringae spp. interfered with the colony morphology of E. amylovora due to levan production, and the CCT plates should be monitored in UV light for the presence of fluorescent $P$. syringae pathovars.

The reliability of serological assays depends on the quality of the antisera. Polyclonal antibodies can cross-react with many bacteria due to common surface antigens (26). Previously described monoclonal antibodies were too specific to identify all E. amylovora strains (20).

Several molecular assays have been proposed to screen for E. amylovora. DNA hybridization was done with DNA fragments from the $29 \mathrm{~kb}$ plasmid, common to all E. amylovora strains (10). The fast, specific, and sensitive PCR assays were first based on information from plasmid pEA29 (6) and were recently supplemented with primers from the chromosomal ams region, the band pattern from $16 \mathrm{~S}$ rDNA amplification with a subsequent HaeIII digest, and arbitrarily-primed (AP)-PCR with primers from transposon Tn5 (4), and with primers derived from a random genomic fragment (13). Nested PCR made detection of $E$. amylovora even more sensitive (21). The high sensitivity can produce false positive signals. PCR also detects non-viable cells. In case of a positive signal, it is also difficult to isolate the pathogen when other bacteria dominate the sample. Therefore, selective conditions for $E$. amylovora which can be exploited for isolation of the pathogen from field samples with other bacteria are highly desirable.

In this study, we use the formation of mucoid yellow colonies on a minimal agar with $\mathrm{CuSO}_{4}$ for identification of E. amylovora. The pathogen was further identified by capsule staining with FITC-labeled lectin from Abrus precatorius.

\section{MATERIALS AND METHODS}

Bacterial strains and media. The bacterial strains investigated are listed in Table 1. 

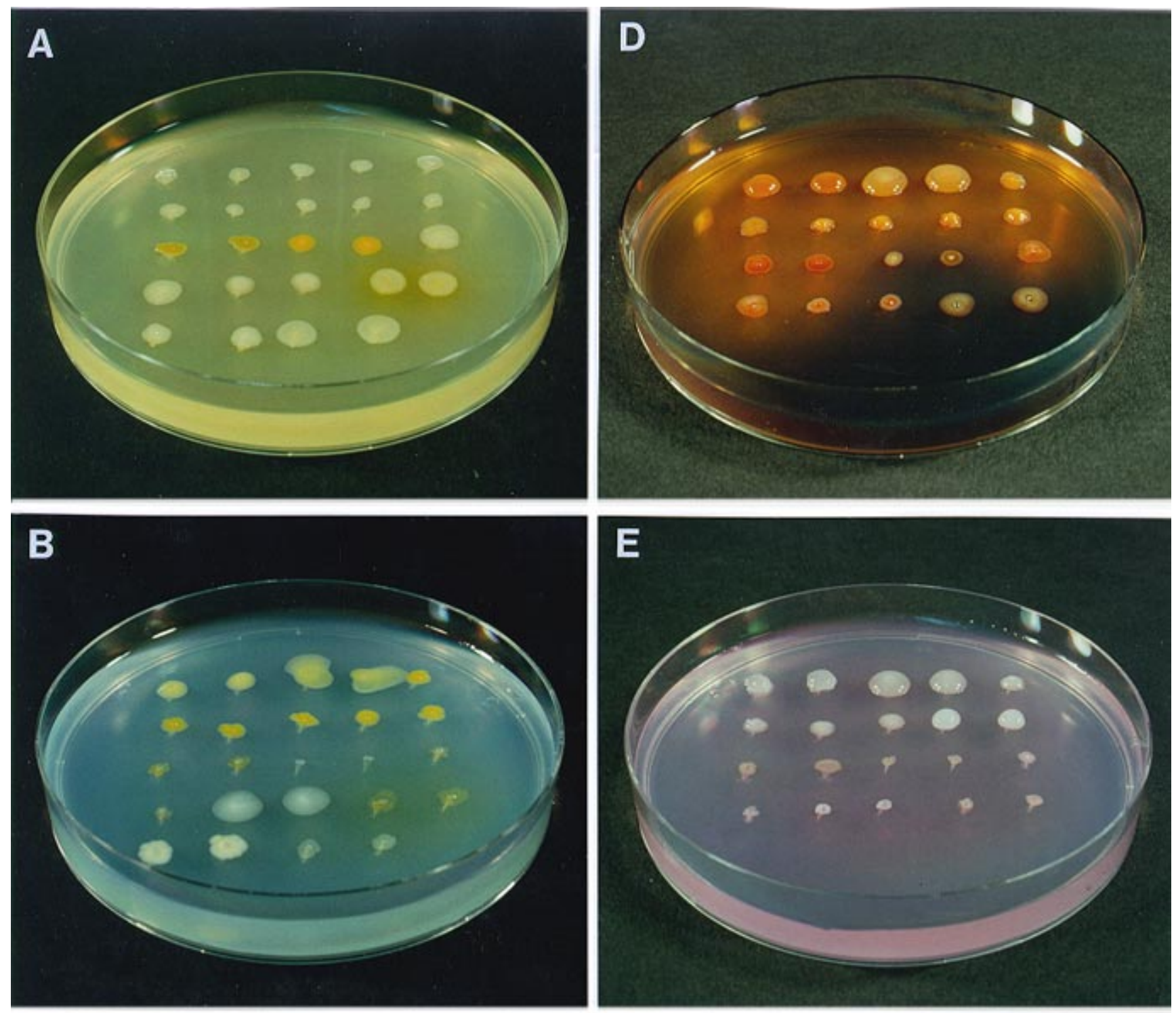

E
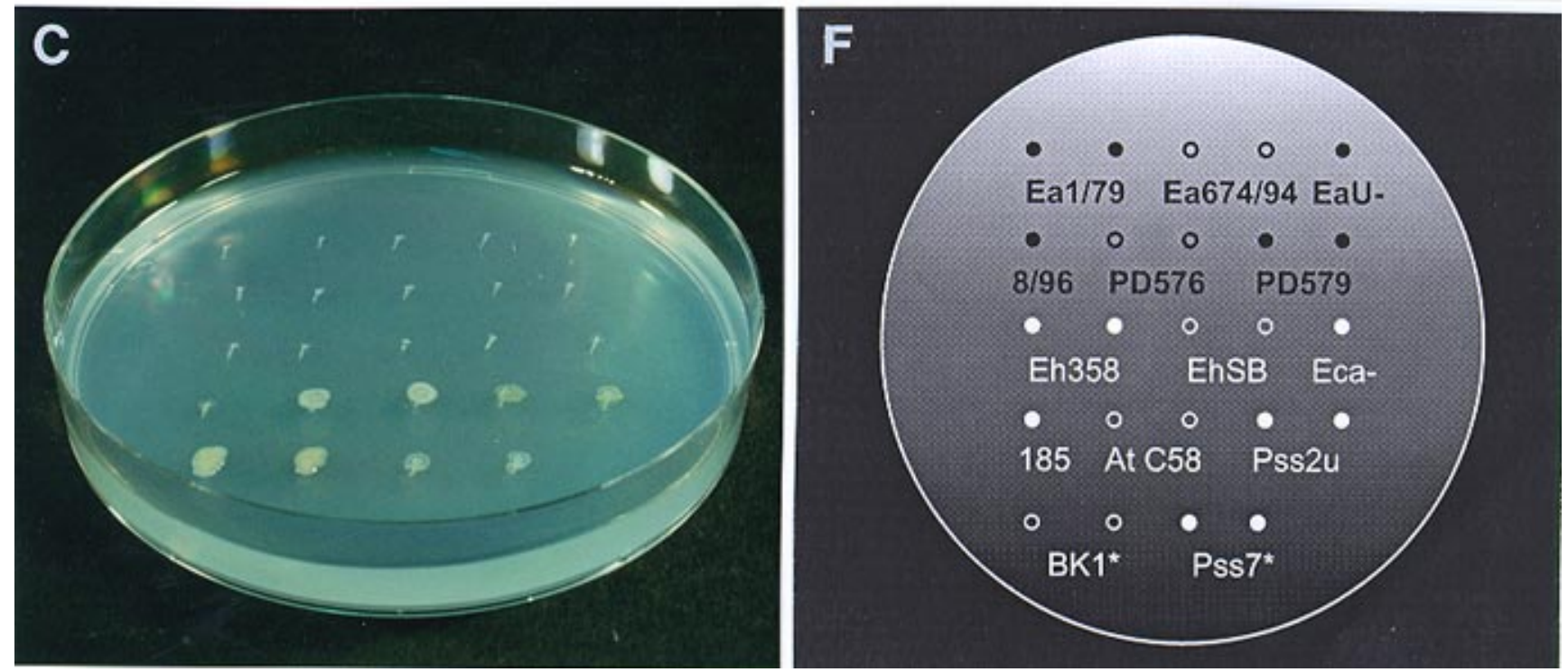

Fig. 1. Growth of Erwinia amylovora and other plant-associated bacteria on various solidified media: (A) LB; (B) MM2Cu; (C) MM1Cu; (D) NSA; and (E) CCT. (F) Scheme for strains applied: Ea and PD, E. amylovora, Ea1/79 (Germany), Ea674/94 (Austria), EaU8/96 (Utah, United States), PD576 and PD579 (levan-deficient strains from the Netherlands); Eh, E. herbicola; Eca, E. carotovora subsp. atroseptica; At, A. tumefaciens; Pss, P. syringae pv. syringae; BK1, unidentified bacterium from a pear tree. The marked strains $(*)$ are high in levan production and were omitted from plates with sucrosecontaining agar (NSA and CCT). Incubation was at $28^{\circ} \mathrm{C}$ for 2 days in the case of LB, 3 days for the sucrose-containing media, and 4 days for MM2Cu and $\mathrm{MM} 1 \mathrm{Cu}$. 
MM1 medium (27) contains $1.5 \mathrm{~g}$ Lasparagine, $3.5 \mathrm{~g} \mathrm{~K}_{2} \mathrm{HPO}_{4}, 1.5 \mathrm{~g} \mathrm{KH}_{2} \mathrm{PO}_{4}$, $1 \mathrm{~g}\left(\mathrm{NH}_{4}\right)_{2} \mathrm{SO}_{4}, 5 \mathrm{mg} \mathrm{MgSO}{ }_{4} \cdot 7 \mathrm{H}_{2} \mathrm{O}, 0.25 \mathrm{~g}$ sodium citrate $2 \mathrm{H}_{2} \mathrm{O}$ ), $0.25 \mathrm{~g}$ nicotinic acid, $0.2 \mathrm{~g}$ thiamin hydrochloride, and $10 \mathrm{~g}$ sorbitol per liter. Medium MM2 (1) is similar to the ASP medium described by Bennett and Billing (3) and consists of 4.0 g L-asparagine, $2.0 \mathrm{~g} \mathrm{~K} \mathrm{~K}_{2} \mathrm{HPO}_{4}, 0.2 \mathrm{~g}$ $\mathrm{MgSO}_{4} \cdot 7 \mathrm{H}_{2} \mathrm{O}, 3.0 \mathrm{~g} \mathrm{NaCl}, 0.2 \mathrm{~g}$ nicotinic acid, $0.2 \mathrm{~g}$ thiamin hydrochloride, and $10 \mathrm{~g}$ sorbitol per liter. Nicotinic acid and thiamin were filter sterilized and added after autoclaving. LB is Luria-Bertani broth with $10 \mathrm{~g}$ bactotryptone, $5 \mathrm{~g}$ yeast extract, and $10 \mathrm{~g} \mathrm{NaCl}$, adjusted to $\mathrm{pH} 7.5$. Rou- tinely, $2 \mathrm{mM} \mathrm{CuSO}_{4}$ were added to MM2 medium, and the agar concentration was $1.5 \%(\mathrm{MM} 2 \mathrm{Cu})$. To avoid fungal growth from field samples, dilutions were plated on nutrient agar (LB) with $50 \mu \mathrm{g}$ of cycloheximide per $\mathrm{ml}$. The plates were incubated at $28^{\circ} \mathrm{C}$ in plastic bags or as sealed petri dishes.

Lectin staining. Bacteria were grown on $\mathrm{MM} 2 \mathrm{Cu}$ agar, transferred with the tip of a needle to a glass slide, and suspended in $5 \mu \mathrm{l}$ of FITC-labeled lectin from A. precatorious (Sigma Chemical Co., St. Louis). The preparation was visualized without further treatment in a Zeiss microscope Axiovert $405 \mathrm{M}$ with an oil immersion lens at 1000 fold total magnification and the filter combination BP450-490/FT510/ LP520 (excitation filter/dichroic/emission filter) as described previously (1).

Detection of $E$. amylovora in field samples. Ten small leaves from $\mathrm{Co}$ toneaster floccosus were cut in stripes and suspended in $10 \mathrm{ml}$ of sterile water for 30 min. Dilutions were plated on LB agar with cycloheximide. On parallel plates, $E$. amylovora cells from overnight cultures of strain Ea1/79 were added to obtain approximately $100 \mathrm{CFU}$ per plate. From plates with about 200 colonies, cells of 25 white colonies were transferred to $\mathrm{MM} 2 \mathrm{Cu}$ agar, and color and mucoidy of the devel-

Table 1. Growth pattern of plant-associated bacteria on MM2 minimal medium with copper sulfate

\begin{tabular}{|c|c|c|c|c|c|c|}
\hline $\begin{array}{l}\text { Species or pathovar, } \\
\text { origin }\end{array}$ & Strain $^{v}$ & $\begin{array}{l}\text { Growth on } \\
\mathrm{MM}^{2} \mathrm{Cu}^{\mathrm{w}}\end{array}$ & $\begin{array}{c}\text { Yellow } \\
\text { colonies }^{w}\end{array}$ & Mucoidy $^{x}$ & $\begin{array}{l}\text { Growth on } \\
\text { MM1Cuw }^{w}\end{array}$ & $\begin{array}{c}\text { Properties- } \\
\text { (sources, references) }\end{array}$ \\
\hline \multicolumn{7}{|l|}{ Erwinia amylovora } \\
\hline \multirow[t]{4}{*}{ Germany } & 42 strains & + & + & + & - & \\
\hline & M5/87y & + & - & + & - & \\
\hline & $\mathrm{Ea}-\mathrm{Ki}$ & + & + & + & - & $\begin{array}{l}\text { (From cherry tree; } \\
\text { E. Geßner, Münster) }\end{array}$ \\
\hline & Ea-Eb & + & + & + & - & (From strawberry) \\
\hline \multirow{2}{*}{ Egypt } & 20 strains & + & + & + & - & \\
\hline & $\mathrm{Ea} 25 / 82$ & + & - & \pm & - & White colonies! \\
\hline England & Ea595, Ea771, Ea775, T & + & + & + & - & \\
\hline France & 3 strains & + & + & + & - & \\
\hline Netherlands & Ea1951 & + & + & + & - & (10) \\
\hline Levan-deficient & $\begin{array}{l}\text { PD207, PD350, PD439, } \\
\text { PD494, PD576, PD579 }\end{array}$ & + & + & + & - & (5) \\
\hline New Zealand & Ea1496/66, Ea8439-83 & + & + & + & - & \\
\hline Turkey & T90, T91 & + & + & \pm & - & \\
\hline \multirow[t]{2}{*}{ North America } & Eam7, E9, Ea266, Ea273 & + & + & + & - & \\
\hline & $\mathrm{Ea}-\mathrm{Rb}$ & + & + & + & - & From raspberry \\
\hline \multirow[t]{6}{*}{ Mutants } & $\begin{array}{l}\mathrm{EaX} 7 / 74, \mathrm{EaX} 1 / 79, \\
\mathrm{EaX} 11 / 88\end{array}$ & + & + & + & - & $\begin{array}{l}\text { Cured from pEA29 } \\
\text { (11) }\end{array}$ \\
\hline & $\begin{array}{l}\text { Ea7/74-A33, } \\
\text { Ea1/79-A33 }\end{array}$ & + & + & - & - & $\operatorname{ams\mathrm {B}(2)}$ \\
\hline & Ea1/79-M1 & + & + & - & - & galE (22) \\
\hline & P66 & + & + & + & - & hrp \\
\hline & $\mathrm{S}$ & + & + & \pm & - & galE \\
\hline & E8 & + & + & - & - & $r c s \mathrm{~B}$ \\
\hline Agrobacterium tumefaciens & 542, Ach5, C58*, T37 & + & - & \pm & + & \\
\hline Erwinia ananas & $\mathrm{Cu} 2093$ & $(+)$ & - & - & & S. Beer \\
\hline \multicolumn{7}{|l|}{ Erwinia carotovora } \\
\hline subsp. atroseptica & $185^{*}$ & $(+)$ & $\mathrm{b}$ & - & & \\
\hline subsp. carotovora & $568,573,582^{*}$ & $(+)$ & - & - & & \\
\hline Erwinia chrysantemi & 540 & $(+)$ & - & - & & \\
\hline \multirow[t]{3}{*}{ Erwinia herbicola } & $358, \mathrm{~A} 1 / 81^{*}, \mathrm{SB}^{*}$ & $(+)$ & $\mathrm{yb}$ & - & - & \\
\hline & $\mathrm{NZ}^{*}$ & + & $\mathrm{yb}$ & \pm & + & \\
\hline & Eh1/93 & + & $y b$ & + & + & From bark of a pear tree \\
\hline Erwinia stewartii & 449, DC $283^{*}$ & $(+)$ & \pm & - & & \\
\hline \multicolumn{7}{|l|}{ Pseudomonas syringae } \\
\hline pv. glycinea & $\begin{array}{l}\text { 27a/90, 43a/90, S8/83, } \\
\text { S19/84, S30/85* }\end{array}$ & $(+)$ & - & - & & \\
\hline pv. maculicola & 438 & - & & & & \\
\hline pv. mors-prunorum & $37 / 4,139,183,753$ & $(+)$ & - & - & & \\
\hline pv. phaseolicola & $6 / 0^{*}, 181 / 4 \mathrm{a}$ & - & & & & \\
\hline \multirow[t]{3}{*}{ pv. syringae } & $359,524 *, \mathrm{~B} 1 *, \mathrm{C} 72$ & $(+)$ & - & - & & \\
\hline & dsm60062*, 2U* & + & - & - & + & \\
\hline & J59, J80/2, W50 & - & & & & \\
\hline pv. tomato & $34,106 / 1$ & $(+)$ & - & - & & \\
\hline \multirow[t]{2}{*}{ Bacillus subtilis } & BD170 & - & & & - & H. Matzura \\
\hline & $\mathrm{K}-4-3$ & + & - & + & - & \\
\hline Undefined, ${ }^{\mathrm{z}}$ Germany & $\mathrm{BK} 1^{*}, \mathrm{~W} 4 *$ & + & - & + & + & W. Zeller \\
\hline
\end{tabular}

${ }^{\mathrm{v}}$ When E. amylovora strains were grown on $\mathrm{MM} 2 \mathrm{Cu}$ agar, 27 of 27 strains tested were positive for lectin staining. Other tested strains, designated by $*$, were negative when grown on $\mathrm{MM} 2 \mathrm{Cu}$, minimal agar, or nutrient agar.

${ }^{\mathrm{w}}$ Growth $(+)$ means a significant growth retardation; $\mathrm{b}=$ brown; $\mathrm{yb}=$ yellow to brown.

${ }^{\mathrm{x}}$ Rating of mucoid appearance: $+=$ mucoid at rim of colony to fluidal; $-=$ rough, not mucoid.

y Grew poorly on $\mathrm{MM} 2 \mathrm{Cu}$, with tendency to form white colonies.

${ }^{\mathrm{z}}$ Strains from apple or pear orchards (originally suggested to be E. amylovora). The sources of most strains are listed in references 10 and 29. 
oping colonies were evaluated. Cells from positive colonies were also stained with FITC-labeled lectin. Tissue from inoculated apple seedlings, grown in a phytotron, and bark from apple trees of an orchard with fire blight symptoms were extracted and treated similarly.

\section{RESULTS}

Growth and colony morphology of $E$. amylovora on minimal agar with $\mathrm{CuSO}_{4}$. E. amylovora tends to grow as mucoid colonies on minimal agar, although this morphology can vary for individual strains and with the composition of the medium. For instance, strain Ea7/74 is mucoid on MM1 agar, but not on MM2 agar. We have thus attempted to find conditions that induce exopolysaccharide (EPS)-synthesis for E. amylovora and allow distinction from other plant-associated bacteria. The addition of $2 \mathrm{mM} \mathrm{CuSO}_{4}$ to MM2 agar increased the mucoid colony morphology of E. amylovora and caused the formation of yellow colonies (Fig. 1B). Bacterial growth decreased for $\mathrm{CuSO}_{4}$ concentrations above $2 \mathrm{mM}$, and the medium had to be neutralized to avoid $\mathrm{pH}$ effects. At 5 $\mathrm{mM} \mathrm{CuSO}_{4}$, growth of E. amylovora was almost abolished. Spontaneous copperresistant mutants were observed, which were able to grow at even higher $\mathrm{CuSO}_{4}$ concentrations. In contrast to mucoid parent strains, the $\mathrm{Cu}$-resistant mutants were non-mucoid on MM2 agar and barely produced ooze on slices of immature pears. EPS synthesis of the mutants was partially restored in the presence of $\mathrm{CuSO}_{4}$. None of the strains in our collection was highly resistant to copper, although some of the Egyptian strains grew better at $5 \mathrm{mM}$ $\mathrm{CuSO}_{4}$ than most of the other strains. For isolation of E. amylovora from field samples, the cells should be grown in parallel on $\mathrm{MM} 2 \mathrm{Cu}$ agar and on agar without $\mathrm{CuSO}_{4}$ in order to avoid selection for partial resistance. When $2 \mathrm{mM} \mathrm{CuSO}_{4}$ was added to MM1 agar, strong growth inhibition was observed for E. amylovora in contrast to formation of yellow, mostly mucoid colonies on MM2Cu agar. When 4 $\mathrm{g}$ asparagine were added to MM1 instead of $1.5 \mathrm{~g}$, used in the original medium, growth and the mucoid yellow morphology was similar to $\mathrm{MM} 2 \mathrm{Cu}$. The permissive component in MM2 medium is thus the high content of asparagine, which might form a complex with copper ions.

Identification of $E$. amylovora on a minimal agar with $\mathrm{CuSO}_{4}$. Most $E$. amylovora strains assayed grew well on MM2 agar containing $2 \mathrm{mM} \quad \mathrm{CuSO}_{4}$ $(\mathrm{MM} 2 \mathrm{Cu})$, and formed yellow colonies that became mucoid in the course of incubation to various extents (Fig. 1B, 2A; Table 1). Among about 100 E. amylovora strains isolated in various geographic regions and at different times, only strain Ea25/82 from Egypt formed white colonies on $\mathrm{MM} 2 \mathrm{Cu}$ agar, although this strain was unambiguously $E$. amylovora by other criteria such as PCR and pulsed-field gel electrophoresis (PFGE) analysis. The best $\mathrm{CuSO}_{4}$ concentration to obtain yellow colonies was $2 \mathrm{mM} \mathrm{CuSO}_{4}$. Good growth on $\mathrm{MM} 2 \mathrm{Cu}$ and the yellow, mostly mucoid colonies were typical for E. amylovora and useful to differentiate the pathogen from other plant-associated bacteria. At $1 \mathrm{mM}$ $\mathrm{CuSO}_{4}$, the colonies of E. amylovora grew faster and were more mucoid, but their yellow color was slightly diminished compared to growth on $2 \mathrm{mM} \mathrm{CuSO}_{4}$. For some strains, mucoidy on $\mathrm{MM} 2 \mathrm{Cu}$ agar was confined to the rim of colonies even after a long incubation time, whereas others were already mucoid at the second day of incubation and turned fluidal afterwards (Fig. 1B). Weak mucoidy could result in crater-like colonies, and the colonies were deep yellow in contrast of a lighter color of fluidal colonies. The degree of EPS production varied for individual strains, and could be used to distinguish some of them from each other (Fig. 2A). For the three German strains, mucoidy increased for Ea7/74, and Ea1/79 to Ea11/88. The Egyptian strain Ea5/84, the Turkish strain T90, and the French strain CNPB1367 (Ea321) were barely mucoid, whereas the English strain T was quite fluidal (Fig. 2A, row 3 ). High mucoidy was also observed for the North American strains Ea266, E273, and E9. The plasmid-free strain EaX1/79 was as mucoid as the parent strain. Occasionally, the transfer of the same colony to several sites on an $\mathrm{MM} 2 \mathrm{Cu}$ agar plate could result in differences of mucoidy. An example is the Rubus strain Ea-Rb in Fig. 2A (row 5). Since the addition of copper ions increased mucoidy of strains tested, we assumed an induction of amylovoran synthesis, which is encoded by the chromosomal ams region (8). This was confirmed by determination of amylovoran production with the CPC assay for strain Ea1/79 (1). During the log-phase, a twofold increase of the EPS concentration was observed in the presence of $2 \mathrm{mM} \mathrm{CuSO}_{4}$ in MM2 medium, whereas sodium sulfate had no effect on amylovoran synthesis. Incubation at temperatures lower than $28^{\circ} \mathrm{C}$ retarded the growth of E. amylovora colonies, but could occasionally increase their mucoid appearance. Mutants without EPS-synthesis were not changed in their non-mucoid phenotype, but also produced yellow colonies. The yellow color is thus not dependent on formation of capsular EPS, and also not on the presence of the common plasmid pEA29 as observed for plasmid cured strains (Table 1).

Differentiation of $E$. amylovora from other plant-associated bacteria. Several species of plant-pathogenic bacteria were assayed on semi-selective plates (Fig. 1) in order to identify E. amylovora. Transfer of colonies to LB agar not only avoided exposure of E. amylovora to copper ions during isolation, but also is a crucial step for the separation of yellow bacteria (Fig. 1A). This step excluded E. herbicola, here strains Eh358 and EhSB, but also E. stewartii strains. E. amylovora formed white colonies on LB agar, which were bright yellow on MM2Cu (Fig. 1B). No other bacterial species produced a similar shift in the color of colonies when plated on these two media. We used several recently isolated E. amylovora strains and compared them with the standard strain Ea1/79 of our laboratory, which formed mucoid yellow colonies. Strain Ea674/94 was as mucoid, whereas EaU8/96, PD576, and Pd579 were weakly mucoid and formed crater-like yellow colonies on MM2Cu. All E. amylovora strains did not grow on $\mathrm{MM} 1 \mathrm{Cu}$ (Fig. 1C). They were also compared for their colony morphology on the sucrose-containing media CCT and NSA, which should cause levan production of E. amylovora (Fig. 1D and E). Strains PD576 and PD579 were recently characterized for their deficiency for levan synthesis (5). Strain EaU8/96 had similar
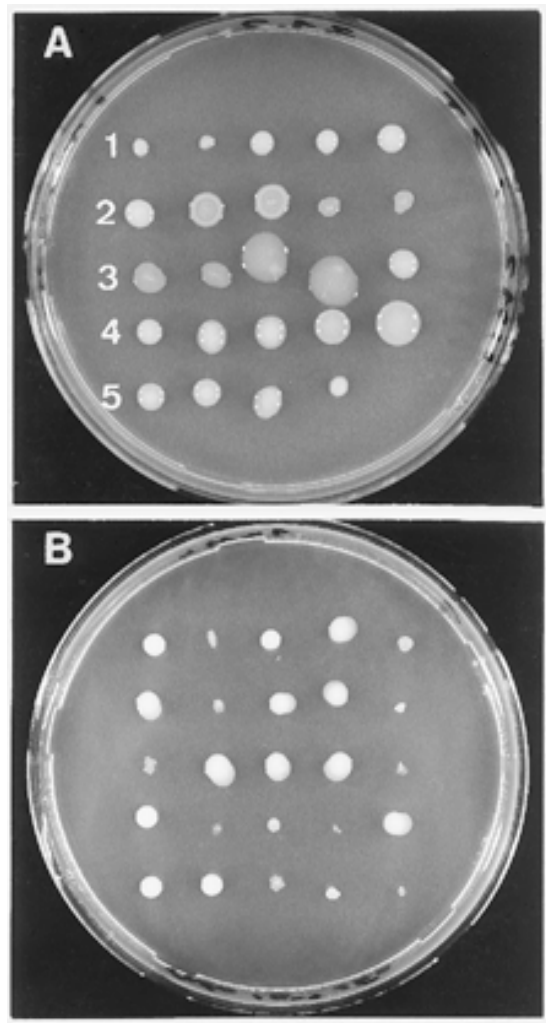

Fig. 2. Typical growth morphology of Erwinia amylovora on minimal agar MM2 with $2 \mathrm{mM}$ $\mathrm{CuSO}_{4}$ (MM2Cu). (A) Two colonies of strains Ea7/74 (row 1), Ea1/79 (row 1), Ea11/88 (Germany; rows 1/2), Ea5/84 (Egypt; row 2), T90 (Turkey; row 2), CNPB1367 (Ea321, France; row 3), T (England; row 3), Ea266 (rows 3/4), Eam7 (row 4), E9 (United States: row 4), EaX1/79 (Ea1/79 without plasmid pEA29; row 5), and Ea-Rb (row 5) were transferred in this order. (B) E. amylovora Ea1/79 was added to a water extract from cotoneaster leaves, and 25 colonies were randomly picked on $\mathrm{MM} 2 \mathrm{Cu}$ agar. Incubation was for 4 days at $28^{\circ} \mathrm{C}$. 
properties, which made CCT or NSA barely suitable for identification of levandeficient strains. Two strains in the last row of Figure 1, BK1 and Pss7, were originally isolated as fire blight suspects. Their levan production flooded the CCT and NSA plates and thus caused identification problems on sucrose media. Both strains were therefore not applied to these plates, but could be clearly distinguished from $E$. amylovora on $\mathrm{MM} 2 \mathrm{Cu} / \mathrm{MM} 1 \mathrm{Cu}$. King's medium B (18) may be used to confirm the absence of fluorescent $P$. syringae pathovars. Some Pseudomonas spp. barely grew on minimal medium with $\mathrm{CuSO}_{4}$. Coronatine-producing strains of the $P$. syringae pathovars atroseptica, glycinea, morsprunorum, and tomato were able to grow on nutrient agar with $2 \mathrm{mM}$ $\mathrm{CuSO}_{4}$ (29), but they did not produce yellow colonies on MM2Cu (Table 1). Agrobacterium tumefaciens produced a mucoid, white colony type and grew on $\mathrm{MM} 1 \mathrm{Cu}$ agar. Two strains of Bacillus subtilis, Gram-positive bacteria, did not grow on $\mathrm{MM} 1 \mathrm{Cu}$, but one strain also produced white mucoid colonies on MM2Cu (Table 1). Strains of the E. carotovora group barely grew on $\mathrm{MM} 2 \mathrm{Cu}$ and could be easily distinguished from E. amylovora. On CCT and NSA, they could produce a similar morphology as levan-deficient $E$. amylovora strains. In rare cases, colonies were mucoid on LB agar, and it was difficult to see a possible yellow color. Transfer occasionally gave rise to a mucoid yellow colony on $\mathrm{MM} 2 \mathrm{Cu}$. A strain isolated from

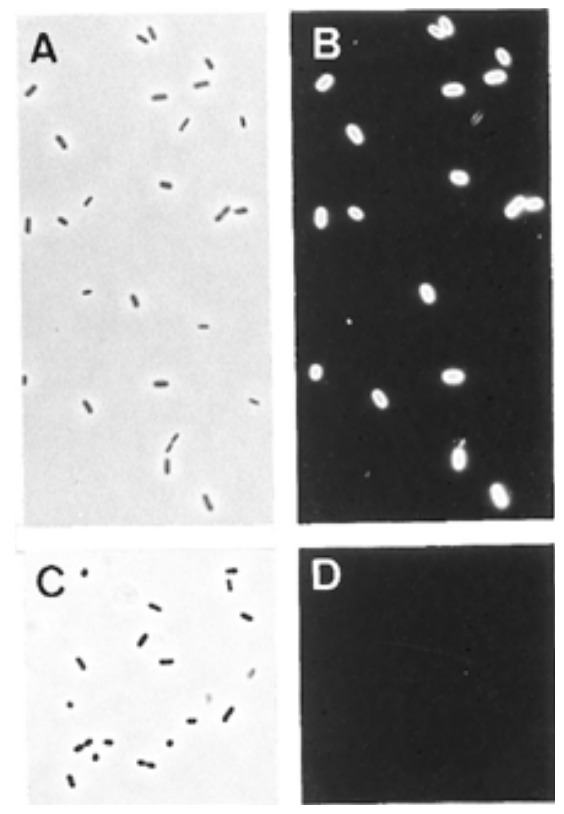

Fig. 3. Identification of Erwinia amylovora by capsule staining. The bacteria were taken from colonies on $\mathrm{MM} 2 \mathrm{Cu}$ agar. The cells were stained with FITC-labeled lectin from A. precatorius and visualized in (A) bright field and (B) UV light as described in Methods. The corresponding experiment with E. herbicola strain NZ is shown in panels (C) and (D). bark with this property could be distinguished from E. amylovora by its growth on $\mathrm{MM} 1 \mathrm{Cu}$. It was later identified as $E$. herbicola. In such rare cases and for confirmation purposes, an additional method is advantageous to identify E. amylovora.

Specific staining of the capsule with FITC-labeled lectin. Lectins from plants are known for specific binding to sugar residues. We recently observed that lectin from Abrus precatorius binds to the amylovoran capsule, presumably by the recognition of galactose residues in the repeating unit of the EPS, since binding was abolished after addition of galactose (1). Furthermore, we noticed that FITC-labeled lectin was not able to stain the capsule of E. stewartii. The structure of stewartan is similar to that of amylovoran, but stewartan carries a terminal glucose residue in the side chain and a glucose residue in the backbone $(24,25)$. Consequently, we assayed other plant pathogenic bacteria for a reaction with FITC-labeled lectin and found that only capsules of E. amylovora (Fig. 3A, B), but not cells of E. herbicola (Fig. 3C, D), E. carotovora subsp. carotovora, E. stewartii, A. tumefaciens strains, or $P$. syringae pathovars were stained (Table 1). Visualization of E. amylovora capsules requires the commercially available FITC-labeled lectin from A. precatorius, a suitable fluorescence microscope, and a bacterial growth medium suited for induction of amylovoran synthesis. Agar plates with $\mathrm{MM} 2 \mathrm{Cu}$ were reliable to induce capsule formation for all E. amylovora investigated except for EPS-deficient mutants, although capsules were also produced on other media to a variable extent and could be stained with the lectin. Since amylovoran synthesis is strictly required for virulence, EPS-mutants have to be selected in the laboratory. Cells of $E$. amylovora wild type strains, which barely formed mucoid colonies on MM2 agar, were often mucoid on $\mathrm{MM} 2 \mathrm{Cu}$ agar and were stained by the lectin. In general, other plant-associated bacteria of our lab collection or from field samples did not react with the lectin. Their growth on media other than $\mathrm{MM} 2 \mathrm{Cu}$ also did not result in positively stained cells. Faint staining or irregular association of the lectin may occasionally occur for bacterial cells. For $E$. amylovora, usually more than $80 \%$ of the cells were intensively stained, although some strains were capsulated to a lower degree. In combination with the typical colony morphology of E. amylovora on $\mathrm{MM} 2 \mathrm{Cu}$ agar, the lectin staining allowed the unambiguous identification of the fire blight pathogen E. amylovora without applying DNA-based techniques.

Identification of $E$. amylovora in the presence of other bacteria. Analysis of field samples is often commenced by plating on semi-selective medium. Transfer of cells from colonies on LB agar plates to $\mathrm{MM} 2 \mathrm{Cu}$ agar gave rise to mucoid yellow colonies if they were formed by E. amylovora (Fig. 2B). Small colonies from agar were already suitable for transfer. We preferred LB medium as nutrient agar, since it is simple to prepare and allows fast growth of colonies. Any other growth medium can also be suitable for transfer of colonies. To inhibit growth of fungi and yeasts, cycloheximide was added to the growth medium. A comparison of plating efficiencies showed little effect of cycloheximide, and equal plating efficiencies for E. amylovora were observed on MM2- and $\mathrm{MM} 2 \mathrm{Cu}$ agar. When field samples were directly plated on $\mathrm{MM} 2 \mathrm{Cu}$ agar, E. amylovora only produced the mucoid yellow colonies at low densities of colony forming bacteria; otherwise, E. amylovora retained a white colony color. It was therefore risky to attempt identification of E. amylovora by straight plating of field samples on $\mathrm{MM} 2 \mathrm{Cu}$ agar. Specifically, fluorescent Pseudomonas syringae pvs. can interfere with $E$. amylovora in formation of yellow colonies on $\mathrm{MM} 2 \mathrm{Cu}$ agar. This interference could be prevented by limiting the number of colonies on standard size petri dish plates (9-cm diameter) to about 25 . Depending on the bacterial strains, an increase of the colony density to 50 was often preserving the yellow morphology, whereas 100 E. amylovora colonies per plate were still mucoid with a tendency of white appearance. Occasionally, colonies were yellow during early incubation times and became white at late stages.

The E. amylovora strains Ea1/79 and Ea7/74 and the $P$. syringae pv. syringae strains $2 \mathrm{U}$ and 60062 were transferred to $\mathrm{MM} 2 \mathrm{Cu}$ plates by picking 24 colonies in an alternating order. At a higher density of colonies per plate, the $P$. syringae pv. syringae strains interfered with the yellow appearance of the E. amylovora colonies. Although strain Ea7/74 rarely forms mucoid colonies on MM2 agar, the $\mathrm{CuSO}_{4}$ induced EPS production. When cells from strains with barely mucoid colonies were treated with FITC-labeled lectin from $A$. precatorius, most of them were capsulated; i.e., fluidal colonies are produced by excessive amounts of EPS.

Detection of $\boldsymbol{E}$. amylovora in field samples. From Cotoneaster floccosus, 10 leaves were extracted by shaking them in $10 \mathrm{ml}$ of sterile water. The suspension was diluted to produce about 100 colonies of microorganisms, and cells from Ea1/79 cultures were added to give about 100 colonies of E. amylovora. An aliquot of 0.2 $\mathrm{ml}$ was plated on LB agar with cycloheximide, and the plates were incubated for 2 days at $28^{\circ} \mathrm{C}$. Then, 25 random colonies were transferred with toothpicks to $\mathrm{MM} 2 \mathrm{Cu}$-plates, which were incubated for 3 to 5 days at $28^{\circ} \mathrm{C}$. About half of the colonies displayed a mucoid yellow appearance (Fig. 2B). When the E. amylovora cells were not added to the extract, this morphology was not observed for any colony 
after transfer to $\mathrm{MM} 2 \mathrm{Cu}$ agar. Confirmation was obtained by staining cells from those colonies with FITC-labeled lectin from $A$. precatorius.

Apple seedlings were inoculated with $E$. amylovora strains Ea7/74 or Ea1/79. Leaves with weak symptoms were extracted with water, the diluted samples were plated on LB agar, and 25 colonies were transferred to $\mathrm{MM} 2 \mathrm{Cu}$ agar. Most of them had the typical mucoid yellow colony morphology and were positive in capsule staining. Two samples were taken from an experimental orchard near Logan, Utah, United States. The first stem section was derived from an apple tree that had been inoculated with an E. amylovora strain carrying nalidixic acid resistance. The other tree was located in an untreated control section of the orchard, but also showed symptoms of fire blight. Bark from these trees was extracted, aliquots of the suspension plated on LB agar, and colonies transferred to $\mathrm{MM} 2 \mathrm{Cu}$ agar. Again, in both assays most colonies had the typical morphology of E. amylovora, and they were positive in lectin staining. Furthermore, these cells were resistant to nalidixic acid (Ea8865nr/96) in contrast to the second set, which was apparently derived from a natural infection (EaU8/96). The latter strain was barely mucoid on $\mathrm{MM} 2 \mathrm{Cu}$ agar (Fig. 1B) and also low in levan synthesis. The yellow growth morphology and lectin staining unambiguously identified $E$. amylovora from plant tissue. Additionally, the system also allowed to identify and to isolate the fire blight pathogen in samples with an excess of other plant-associated bacteria. For practical reasons, this mixture should contain at least one culturable $E$. amylovora cell in $25 \mathrm{CFU}$ to limit the number of the $\mathrm{MM} 2 \mathrm{Cu}$ agar plates required for screening the pathogen.

\section{DISCUSSION}

To commence preventive treatments, diagnosis of E. amylovora in field samples is important for the control of fire blight. The great benefit of sensitive and unambiguous identification of E. amylovora with DNAbased methods $(4,6)$ was supplemented here by cultural conditions which resulted in a mucoid yellow colony morphology, typical and specific for the fire blight pathogen. Another novel assay confirmed E. amylovora by staining the bacterial capsules with FITC-labeled lectin.

Copper ions may form a complex with surface components of the cells, resulting in yellow appearance. One variant in our strain collection was white in the presence of $\mathrm{CuSO}_{4}$, but definitely E. amylovora by other criteria. Cells of $E$. herbicola and $E$. stewartii, which have recently been reassigned into the genus Pantoea, are colored by intercalation of carotenoids in the cell wall. A gene cluster involved in carotenoid synthesis of E. herbicola has been recently characterized $(15,28)$. An induction of carotenoid synthesis in E. amylovora by copper ions seems unlikely, since such compounds could not be extracted with organic solvents (unpublished data). Copper ions also cause a change of cell morphology for E. amylovora, such as large cell bodies of oval shape (14). Recently, we noticed an increase of amylovoran synthesis in strains selected for spontaneous resistance to streptomycin and elevated EPS-production in the presence of sorbitol (1), which suggested the high sensitivity of amylovoran synthesis to genetic and environmental conditions. In this study, we observed induction of EPS synthesis by copper ions. However, distortions in the environment could prevent E. amylovora from forming mucoid yellow colonies. Dense plating prevented the yellow growth pattern; the colonies were white, but still mucoid, independent if the surrounding colonies were E. amylovora or other bacteria. A strong interference was observed for fluorescent $P$. syringae pv. syringae strains. About 25 colonies per plate were a safe number with which to identify E. amylovora by the typical growth on minimal agar with $\mathrm{CuSO}_{4}$, although this morphology was often still obtained for much higher colony densities. Staining of capsules with FITC-labeled lectin from $A$. precatorious was another specific assay for E. amylovora. The extent of capsule formation of $E$. amylovora can vary for growth conditions and individual strains (1). The capsules are so fragile that they are largely removed in suspension cultures. Lectin staining should thus be done with cells from a homogenous colony grown on the EPS-inducing $\mathrm{MM} 2 \mathrm{Cu}$ agar, whereas some other solidified media decreased the amount of positive capsules, especially when they contained sucrose (unpublished data).

Copper ions can be strongly inhibitory for growth of E. amylovora. The inhibition can be relieved by high levels of amino acids or citrate (K. Geider, unpublished data). The high content of asparagine in MM2 medium is responsible for suppression of growth inhibition by $\mathrm{CuSO}_{4}$, since an increase of asparagine in MM1 medium restored growth of E. amylovora in the presence of $\mathrm{CuSO}_{4}$. The absence of growth on $\mathrm{MM} 1 \mathrm{Cu}$ is an additional criterion for identification of E. amylovora.

The proposed $\mathrm{MM} 2 \mathrm{Cu}$ agar for detection and identification of E. amylovora has several advantages. It does not depend on levan formation, and colonies of E. amylovora strains display a yellow color and often a mucoid appearance. After repeated testing of a large number of E. amylovora strains from different geographical regions isolated at various times, this morphology was stable and reproducible. The medium is easy to prepare, and rare ambiguous colonies can be further screened by capsule staining with FITC-labeled lectin. Complementary steps for identification of $E$. amylovora on plates are summarized in
Fig. 1. Transfer of cells from the nutrient agar used for the initial plating to LB (white colonies), MM2Cu (yellow colonies), $\mathrm{MM} 1 \mathrm{Cu}$ (no growth), and a sucrosecontaining agar for levan-producing strains are not only useful for detection of the fire blight pathogen but also for its isolation from plant tissue.

\section{ACKNOWLEDGMENTS}

We thank Dr. Esther Moltmann, Stuttgart, Germany, for verifying the new plating technique in her laboratory; and Dr. Carol Bender, Stillwater, Oklahoma, for critical comments on the manuscript.

\section{LITERATURE CITED}

1. Bellemann, P., Bereswill, S., Berger, S., and Geider, K. 1994. Visualization of capsule formation by Erwinia amylovora and assays to determine amylovoran synthesis. Int. J. Biol. Macromol. 16:290-296.

2. Bellemann, P., and Geider K. 1992. Localization of transposon insertions in pathogenicity mutants of Erwinia amylovora and their biochemical characterization. J. Gen. Microbiol. 138:931-940.

3. Bennet, R., and Billing, E. 1980. Origin of the polysaccharide component of ooze from plants infected with Erwinia amylovora. J. Gen. Microbiol. 116:341-349.

4. Bereswill, S., Bugert, P., Bruchmüller, I., and Geider, K. 1995. Identification of Erwinia amylovora by PCR with chromosomal DNA Appl. Environ. Microbiol. 61:2636-2642.

5. Bereswill, S., Jock, S., Aldridge, P., Janse, J. D., and Geider K. Natural levan-deficient Erwinia amylovora strains. Phys. Mol. Plant Pathol. In press.

6. Bereswill, S., Pahl, A., Bellemann P., Zeller W., and Geider K. 1992. Sensitive and species-specific detection of Erwinia amylovora by PCR-analysis. Appl. Environ. Microbiol. 58:3522-3526.

7. Brulez, W., and Zeller, W. 1981. Seasonal changes of epiphytic Erwinia amylovora on ornamentals in relation to weather conditions and course of infections. Acta Hortic. 117:37-43.

8. Bugert, P., and Geider, K. 1995. Molecular analysis of the ams operon required for exopolysaccharide synthesis of Erwinia amylovora. Mol. Microbiol. 15:917-933.

9. Crosse, J. E., and Goodman, R. N. 1973. A selective medium for and a definitive colony characteristic of Erwinia amylovora. Phytopathology 63:1425-1426.

10. Falkenstein, H., Bellemann, P., Walter, S. Zeller, W., and Geider, K. 1988. Identification of Erwinia amylovora, the fire blight pathogen, by colony hybridization with DNA from plasmid pEA29. Appl. Environ. Microbiol. 54:2798-2802.

11. Falkenstein, H., Zeller, W., and Geider, K. 1989. The $29 \mathrm{~kb}$ plasmid, common in strains of Erwinia amylovora, modulates development of fireblight symptoms. J. General Microbiol. 135:2643-2650.

12. Gross, M., Geier, G., Rudolph, K., and Geider, K. 1992. Levan and levansucrase synthesized by the fire blight pathogen Erwinia amylovora. Phys. Mol. Plant Pathol. 40:371381.

13. Guilford, P. J., Taylor, R. K., Clark, R. G., Hale, C. N., and Forster, R. L. S. 1996. PCRbased techniques for the detection of Erwinia amylovora. Acta Hortic. 411:53-56.

14. Hodson, N., and Sigee, D. C. 1991. Copper toxicity in Erwinia amylovora: An X-Ray microanalytical study. Scanning Microsc. 5:427438.

15. Hundle, B., Alberti, M., Nievelstein, V., Beyer, P., Kleinig, H., Armstrong, G. A., 
Burke, D. H., and Hearst, J. E. 1994. Functional assignment of Erwinia herbicola Eho10 carotenoid genes expressed in Escherichia coli. Mol. \& Gen. Genet. 245:406-416.

16. Ishimaru, C., and Klos, E. J. 1984. New medium for detecting Erwinia amylovora and its use in epidemiological studies. Phytopathology 74:1342-1345.

17. Kado, C. I., and Heskett, M. G. 1970. Selective media for isolation of Agrobacterium, Corynebacterium, Erwinia, Pseudomonas, and Xanthomonas. Phytopathology 60: 969-976.

18. King, E. O., Ward, M. K., and Raney, D. E. 1954. Two simple media for the demonstration of pyocyanin and fluorescin. J. Lab. Clin. Med. 44:301-307.

19. Lelliot, R. A. 1967. The diagnosis of fire blight (Erwinia amylovora) and some diseases caused by Pseudomonas syringae. Eur. Mediterr. Plant Protect. Organ. Publ., Ser. A(45-E):27-34

20. Lin, C. P., Chen, T. A., Wells, J. M., and van der Zwet, T. 1987. Identification and detection of Erwinia amylovora with monoclonal antibodies. Phytopathology 77:376-380.

21. McManus, P. S., and Jones, A. L. 1995. Detection of Erwinia amylovora by nested PCR and PCR-dot-blot and reverse-blot hybridizations. Phytopathology 85:618-623.

22. Metzger, M., Bellemann, P., Bugert, P., and Geider, K. 1994. Genetics of galactose metabolism of Erwinia amylovora and its influence on polysaccharide-synthesis and virulence of the fire blight pathogen. J. Bacteriol. 176:450-459.

23. Miller, T. D., and Schroth, M. N. 1972. Monitoring the epiphytic population of $\mathrm{Er}$ winia amylovora on pear with a selective medium. Phytopathology 62:1175-1182.

24. Nimtz, M., Mort, A., Wray, V., Domke, T. Zhang, Y., Coplin, D. L., and Geider, K. 1996. Structure of stewartan, the capsular exopolysaccharide from the corn pathogen Erwinia stewartii. Carbohydr. Res. 288:189-201.

25. Nimtz, M., Mort, A., Wray, V., Domke, T., Zhang, Y., Qiu, F., Coplin, D. L., and Geider, K. 1996. Structure of amylovoran, the capsular exopolysaccharide from the fire blight pathogen Erwinia amylovora. Carbohydr. Res. 287:59-76.

26. Roberts, P. 1980. Problems encountered during immunofluorescence diagnosis of fire blight. Plant Pathol. 29:93-97.

27. Steinberger, E. M., and Beer, S. V. 1988 Creation and complementation of pathogenicity mutants of Erwinia amylovora. Mol. Plant-Microbe Interact. 1:135-144.

28. To, K. Y., Lai, E. M., Lee, L. Y., Lin, T. P., Hung, C. H., Chen, C. L., Chang, Y. S., Liu, S. T. 1994. Analysis of the gene cluster encoding carotenoid biosynthesis in Erwinia herbicola Eho13. Microbiol. 140:331-339.

29. Ullrich, M., Bereswill, S., Völksch, B., Fritsche, W., and Geider, K. 1993. Molecular characterization of field isolates of Pseudomonas syringae pv. glycinea differing in coronatine production. J. Gen. Microbiol 139:1927-1937.

30. Van der Zwet, T., and Keil, H. L. 1979. Fire blight: A bacterial disease of rosaceous plants. Agriculture Handbook no. 510, U.S. Government Printing Office, Washington, DC. 